\title{
Innovative Learning Model: Improving the Students' Scientific Literacy of Junior High School
}

\author{
*Aprido B. Simamora ${ }^{1}$, Wahono Widodo ${ }^{2}$, I Gusti Made Sanjaya ${ }^{3}$ \\ 1,2,3 Doctoral Program of Science Education, Universitas Negeri Surabaya, Surabaya Indonesia \\ 1Universitas HKBP Nommensen Medan, Medan, Indonesia
}

\begin{tabular}{|c|c|}
\hline (A) Check for updates open $\partial_{\text {access }}$ (c) (7) (2) & DOI : https://doi.org/10.46245/ijorer.v1i3.55 \\
\hline Article Info & ABSTRACT \\
\hline Article history: & In the strict challenges faced by society, a paradigm shift is needed in the \\
\hline Submitted: August 3, 2020 & 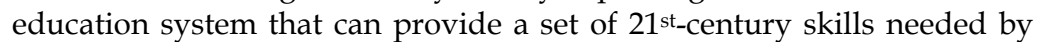 \\
\hline Final Revised: September 18, 2020 & students to deal with every aspect of global life. One of them is scientific \\
\hline Accepted: October 25, 2020 & literacy. Unfortunately, the scientific literacy ability of students in \\
\hline Published online: October 31, 2020 & $\begin{array}{l}\text { Indonesia is still low. The Inquiry and SETS models have been widely } \\
\text { applied to improve students' scientific literacy skills. However, } \\
\text { weaknesses are found such as: students still cannot use their content } \\
\text { knowledge to explain scientific phenomena perfectly; and the need for }\end{array}$ \\
\hline Keyz & more in-depth inquiry activities so that students' abilities in designing \\
\hline BRA & and evaluating scientific investigations obtain excellent results. Therefore, \\
\hline n design research & innovation was created to develop the BRADeR learning model based on \\
\hline Innovative learning & consideration of the strengths and weaknesses of the inquiry model and \\
\hline Learning Model & SETS as well as theoretical and empirical support. This research serves as \\
\hline Science literacy ability & $\begin{array}{l}\text { a preliminary study in the process of developing the BRADeR model to } \\
\text { improve students' scientific literacy skills. This study includes a needs }\end{array}$ \\
\hline 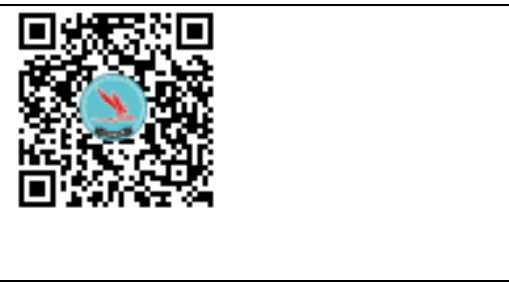 & $\begin{array}{l}\text { analysis and literature review. The results show that innovation can be } \\
\text { maintained as a basis for developing a hypothetical model of the } \\
\text { BRADeR learning model. The syntax of the BRADeR model includes: } \\
\text { brainstorming, reading, analyzing, decision making, and reflection. The } \\
\text { hypothetical model of the BRADeR learning model must be tested to } \\
\text { meet the aspects of validity, practicality, and effectiveness to improve the } \\
\text { scientific literacy skills of junior high school students. }\end{array}$ \\
\hline
\end{tabular}

\section{INTRODUCTION}

Science literacy is one of the skills needed in the 21st century among the 16 skills identified by the World Economic Forum (Wefusa, 2015). Students who know to understand scientific evidence and the relationship between science, technology and society, and can apply their knowledge to solve real-life problems are called scienceliterate societies (Odegard et al., 2015; Wang \& Zhao, 2012). Given the importance of scientific literacy, educating people to have scientific literacy is a major goal in any reform of science education (DeBoer, 2000; Holbrook \& Rannikmae, 2009; Odegard et al., 2015; Wang \& Zhao, 2012).

Development of scientific literacy skills and positive attitudes towards science are the main objectives of science education in several countries (Odegard et al., 2015; Wang \& Zhao, 2012). Students can realize and understand the various impacts of the development of science and technology in real life, dare to make personal decisions about science and its applications, and discuss actions to criticize science issues (Turiman et al., 2012; Situmorang, 2016). Students are equipped with life skills in innovation and careers; facing the development of science and technology; and support sustainable development (Huann et al., 2012; Rahayu 2014; Sani 2014). Students who are 
given science learning have an important role in civilizing the literacy of science in schools and later the life of the community (Holbrook \& Rannikmae, 2009; Odegaard et al., 2015). Thus, students need to have positive attitudes towards science and the ability of scientific literacy to succeed in their lives and careers in the future.

Scientific literacy is one of the problems that is quite important and must be addressed immediately in Indonesia. Based on PISA data (Program for International Student Assessment) the scientific literacy ability of Indonesian students is still below average when compared with the average international score and in general is at the lowest PISA measurement stage. As quoted from The Organization for Economic Cooperation and Development (OECD), Indonesia's ranking in PISA in 2003 was 38th out of 41 with a score of 395. In 2006 Indonesia was ranked 50 th out of 57 with a score of 393. Year 2009 Indonesia was ranked 57th out of 65 with a score of 383. In 2012 Indonesia was ranked 64 th out of a total of 65 countries with a current rating of 382. Furthermore, in 2015 Indonesia was ranked 64th out of 72 participating countries, with a score of 403 (OECD, 2013; OECD, 2016). Based on the survey results Indonesian students' scores on scientific literacy skills are still far below the international standard scores set by the OECD institute.

Several factors influence the low scientific literacy of students. These factors include: (1) science learning habits that are still conventional and ignore the importance of the ability to read and write science as a competency that must be owned by students, so there is a tendency that the learning process does not support students in developing scientific literacy skills (Angraini, 2014; Putra et al., 2016); (2) the ability of students to interpret the graph / Table presented in the problem. Students are accustomed to only filling in the Tables that have been provided by the teacher, so the ability of students to interpret graphs / Tables is also limited (Rahayu, 2014; Hasanah et al., 2017); (3) students are not accustomed to working on scientific literacy test questions. According to students, literacy tests are more difficult than the usual exam questions given by teachers (Rakhmawan et al., 2015; Hasanah et al., 2017). Based on these factors shows that the learning process at school is very influential on the achievement of students' scientific literacy. Besides, teachers have an important role in developing students' scientific literacy in the learning process. Therefore, the problem of the ability of scientific literacy must be resolved immediately.

In connection to the learning process, it helps teachers use a prototype of the learning model. With the learning model, the learning process can be enriched to achieve the expected learning goals. Teachers should be familiar with learning models to integrate positive attitudes towards science so that scientific literacy skills can be improved. But sometimes not all learning models can be adapted to subject matter related to scientific literacy (Rusilowati et al., 2016). Therefore, it is very much needed a learning model that is adapted to natural science subject matter to improving students' scientific literacy skills.

Asyhari \& Clara's research results (2017) found that through the application of inquiry, students still could not use their content knowledge to explain scientific phenomena perfectly. This was also reinforced by Rakhmawan et al. (2018) saying that at the stage of the investigation using the inquiry model, students were not focused on specific decision making, only limited to concluding the results of the data analysis. Retno \& Marlina (2018) revealed that, through the application of the SETS model, the 
problems presented sometimes made student motivation decrease, and were unable to do further work as expected. The results of studies on inquiry models and SETS show the importance of innovation in these models to improve students' scientific literacy skills.

\section{LITERATURE REVIEW}

\section{Scientific Literacy}

\section{Definition of Scientific Literacy}

Scientific literacy is important to be owned by students to be able to address various scientific issues that develop in society. In line with Holbrook \& Rannikmae's (2009) statement that "the evidence from the pilot and the first two years of more general use of the course is that a scientific literacy emphasis can significantly improve students' engagement with science ideas and issues, in schools where teachers have a sound understanding of the rationale for the course and are generally supportive of its aims and aspirations. From this expression, it can be interpreted that the ability of scientific literacy can significantly increase student involvement with ideas and issues about science, then teachers in schools have a good understanding of science so that they can support and accommodate the aspirations of students during their involvement in ideas and science issues during the learning process.

Holbrook \& Rannikmae (2009) developed a definition of scientific literacy that is the target of science education. They suggest the need for appreciation of the nature of science (Nature of Science) and its relevance to the science being studied so that developing scientific literacy through science education is an effort to develop the ability to use scientific knowledge and skills creatively based on sufficient evidence, especially those relevant to career and daily life in solving important problems, and submitting personal arguments in making responsible social-scientific decisions. Besides, scientific literacy also requires the ability to develop skills to interact together, self-development with a communicative approach, and the need to show reasoning that can be understood and persuasive when raising arguments in socioscientific issues (socioscientific issues).

The Program for International Student Assessment (PISA) defines scientific literacy as: "The capacity to use scientific knowledge, to identify questions and to draw evidence-based conclusions to understand and help make decisions about the natural world and the changes made to it through human activity" (OECD, 2016). That definition purpose that scientific literacy is the ability to use scientific knowledge to be a solution in making decisions about nature and changes made through human activities. Furthermore, Lederman et al. (2013) revealed that "the essential nature of scientific literacy is that which influences students' decisions about personal and societal problems. Beyond this, however, educators work to influence students' ability to view science through a more holistic lens." From these expressions, it can be interpreted that the important thing of scientific literacy is that scientific literacy can influence students in decision making when facing personal or social problems, while the role of educators is to influence students' ability to be able to see science holistically.

From the statements above it can be concluded that scientific literacy is an attempt to understand science used to adapt to the challenges of the rapidly changing world. The ability of scientific literacy not only requires students to understand scientific 
knowledge, but students must also be able to understand various aspects of the scientific process and the ability to apply scientific knowledge in real life. In principle, there are 3 general terms agreed upon in scientific literacy, namely: (1) scientific literacy is knowledge of science concepts and ideas; (2) scientific literacy is an understanding of the process of inquiry and the nature of how to obtain knowledge (nature of science); and (3) scientific literacy is an awareness of the influence of scientific activities on the social context in which they are carried out, and their effects on daily life, personal and social decisions about scientific ideas and their applications.

\section{Indicator of Scientific Literacy}

PISA is updating the indicators of scientific literacy. The scientific literacy indicators established by PISA were previously divided into three dimensions and then changed to four dimensions. There is one additional dimension which is the attitude dimension. Competence in scientific literacy refers to the scientific process involved when answering a question or solving a problem, such as identifying and interpreting evidence and explaining conclusions. This includes knowing the types of questions that can and cannot be answered by science, knowing what evidence is needed in a scientific inquiry, and recognizing conclusions that are following the available evidence. An overview of the scientific framework in PISA 2015 is presented in Figure 1.

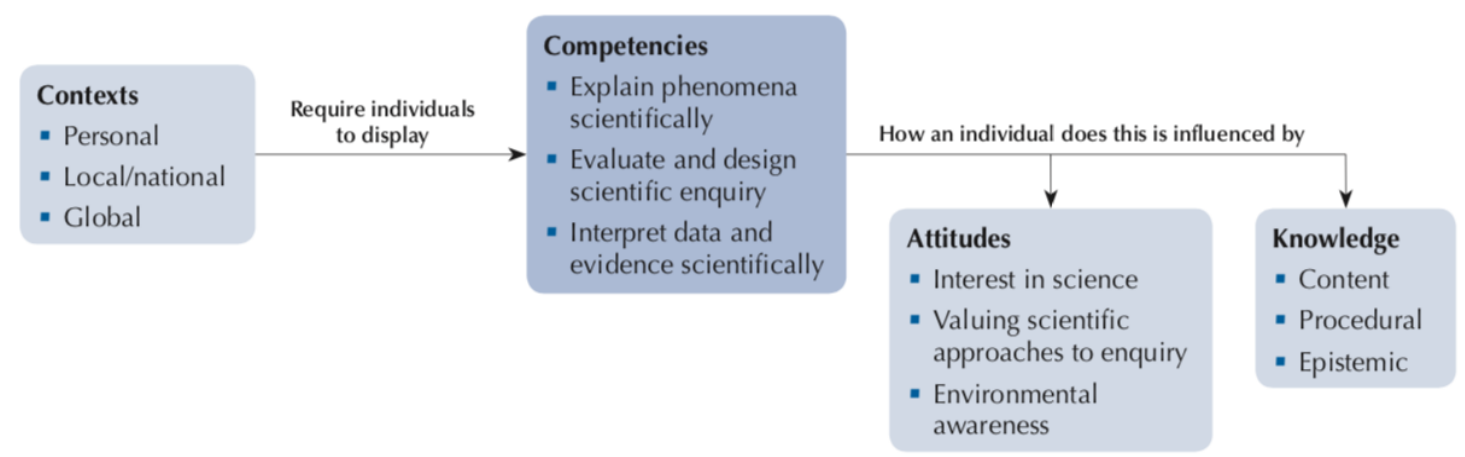

Figure 1. Inter-relation between the four aspects (OECD, 2017).

\section{Assessment in Scientific Literacy}

To assess students' scientific literacy skills, it is necessary to develop a scientific literacy ability test. The developed scientific literacy test is elaborated on the knowledge dimension and competency dimension. In the dimension of knowledge, it is described in 3 (three) types of knowledge, namely: content, procedural, and epistemic knowledge. Furthermore, the competency dimension is broken down into three competencies, namely: explaining scientific phenomena, designing and evaluating scientific inquiry, and interpreting scientific data and evidence.

The level of cognitive demands is needed to analyze the situation presented and synthesize the answers accordingly. According to the scientific literacy framework developed by PISA (OECD, 2016) defines increasing complexity is based on the level of cognitive demands of the three competencies in science assessment. Factors that determine the cognitive demands of each item include the number of elements of knowledge and the level of complexity, the level of familiarity, and initial knowledge of students about content, procedural and epistemic knowledge. Cognitive level is needed 
in each item which includes remembering, analyzing, evaluating, and the extent to which the form of response depends on the model or abstraction of scientific ideas.

\section{Learning Models Applied in Improving Scientific Literacy Ability Inquiry Learning Model}

Inquiry learning is one of the learning models that play an important role in constructing constructivist learning paradigms that emphasize student learning activeness (Ong \& Borich; 2006). Through inquiry learning models, students are trained to develop fundamental scientific abilities which include observing, classifying, calculating, formulating hypotheses, making space and time relations, measuring, interpreting data, and designing experiments (Brown, 2017). McConey (2014) argues that inquiry-oriented learning provides the investigative nature, whereas from a pedagogical perspective inquiry-oriented learning reflects constructivist learning models or active learning.

The teacher tries to engage students in important scientific questions, allows students to explore and make their explanations, provide scientific explanations and help students connect their ideas, and create opportunities for students to expand, apply and evaluate what they have learned. Odegaard et al. (2015) suggested that teachers must understand the level of student knowledge before implementing the inquiry learning model, meaning that the teacher is responsible in terms of: (1) starting the inquiry process; (2) enhance dialogue with students; (3) forming discussion groups; (4) clear students' misconceptions about materials, scientific procedures of inquiry and attitudes; and (5) utilizing student experience to form new knowledge.

The syntax/phase of inquiry learning is believed to help students carry out the inquiry process. The following inquiry syntax proposed by Ong \& Boorich (2006) is a general model used by teachers in designing inquiry learning models, namely ask (formulate questions or hypotheses), investigate (plan investigations and collect data), create (analyze data and interpret results), discuss (discuss the findings of the investigation and make conclusions), reflect (reflect and make connections between concepts). The Inquiry Learning Model has strengths and weaknesses. The strengths and weaknesses of the model are presented in Table 1.

Table 1. Strengths and weaknesses of inquiry learning models.

Strengths

\section{Weaknesses}

1. Encourage students to think naturally in every 1 . Students still cannot use their content problem solving they encounter (Wenning; 2010).

2. Helping students use memory and transfer 2 knowledge in new teaching process situations (Wenning; 2010).

3. Encourage students to think at a higher level and work based on their initiative (Anam, 2015).

4. Cultivate an objective, honest and open attitude (Anam, 2015).

5. The situation of teaching and learning process becomes alive and dynamic (Nur, 2008).

6. inquiry learning models can develop individual talents or skills (Odegaard et al., knowledge to explain scientific phenomena perfectly (Asyhari \& Clara, 2017).

2. Student knowledge on the aspect of content is very low because in inquiry learning has not been facilitated the provision of reading material that is scientific and in-depth about the material to be taught (Basam et al., 2018).

3. In the investigation phase, students have not focused on specific decision making, only limited to concluding the results of data analysis (Rakhmawan et al., 2018).

4. The teacher does not have enough knowledge about how to teach students to do science (Tatar \& Oktayim, 2011). 


\section{SETS Learning Model}

SETS as teaching and learning of science in the context of human experience. This means SETS is learning that facilitates the learning of science and technology through experience. This understanding shows that SETS learning emphasizes the importance of learning to understand technical issues and existing scientific issues and influence the community and the environment through experience. In line with the opinion of NC State University (in Zeidler, 2016), SETS is a model that aims to find out how science and technology can change the culture, values, social and environmental processes in society, and how culture, values, social and environmental processes in society influences the development of science and technology.

Yager (1996) purposes that there are 5 (five) phase/syntax of the SETS learning model elaborated by NSTA. The five learning steps are the invitation, exploration, solution, application, and concept strengthening phases. Stage 1: invitation. At this stage, it is a preliminary activity by presenting issues. Stage 2: exploration. At this stage students are expected through their actions and reactions trying to understand/learn new situations or are a problem for him; Stage 3: solution. At this stage, students analyze the occurrence of phenomena and discuss how to solve problems based on exploration results. Students recognize and develop new concepts that are following local environmental conditions. Stage 4: Application. At this stage students use the concepts obtained to carry out concrete actions in overcoming problems raised at the invitation stage; and Stage 5: concept strengthening. during the concept formation process, the completion of the analysis of issues in stages 2 and 3, the teacher needs to straighten out if there are misconceptions during the learning activities. This activity is called reinforcement of concept.

According to Yager et al., (2012) learning using SETS focuses on processes rather than products, so that by the theory of constructivism learning oriented to the formation of knowledge through the process of finding, marking and organizing new data. In line with this opinion, Amirshokoohi (in Retno \& Marlina, 2018) revealed that the SETS framework is based on an interdisciplinary constructivist philosophy that involves students actively in the learning process. Thus the learning theory that underlies the SETS learning model is the constructivism learning theory. SETS learning has advantages and disadvantages. The strengths and weaknesses of the SETS learning model can be presented in Table 2 .

Table 2. Strengths and weaknesses of the SETS learning model.

\begin{tabular}{|c|c|}
\hline Strengths & Weaknesses \\
\hline $\begin{array}{l}\text { 1. Students are directed at the situation to } \\
\text { utilize the concepts of science in the form of } \\
\text { technology that can be utilized for people's } \\
\text { lives (Poedjiadi, 2010). }\end{array}$ & $\begin{array}{l}\text { 1. The problems presented sometimes make } \\
\text { student motivation decrease and unable to do } \\
\text { further work as expected (Retno \& Marlina, } \\
\text { 2018). }\end{array}$ \\
\hline $\begin{array}{l}\text { Students can explain the } \\
\text { relationship/relationship between the } \\
\text { elements of science with other elements in } \\
\text { SETS that influence each other (Poedjiadi, } \\
2010 \text { ). }\end{array}$ & $\begin{array}{l}\text { 2. The need for in-depth investigation activities so } \\
\text { that students' abilities in designing and } \\
\text { evaluating scientific investigations obtain } \\
\text { excellent results. This will be a reference for } \\
\text { students in determining an action in carrying out }\end{array}$ \\
\hline
\end{tabular}




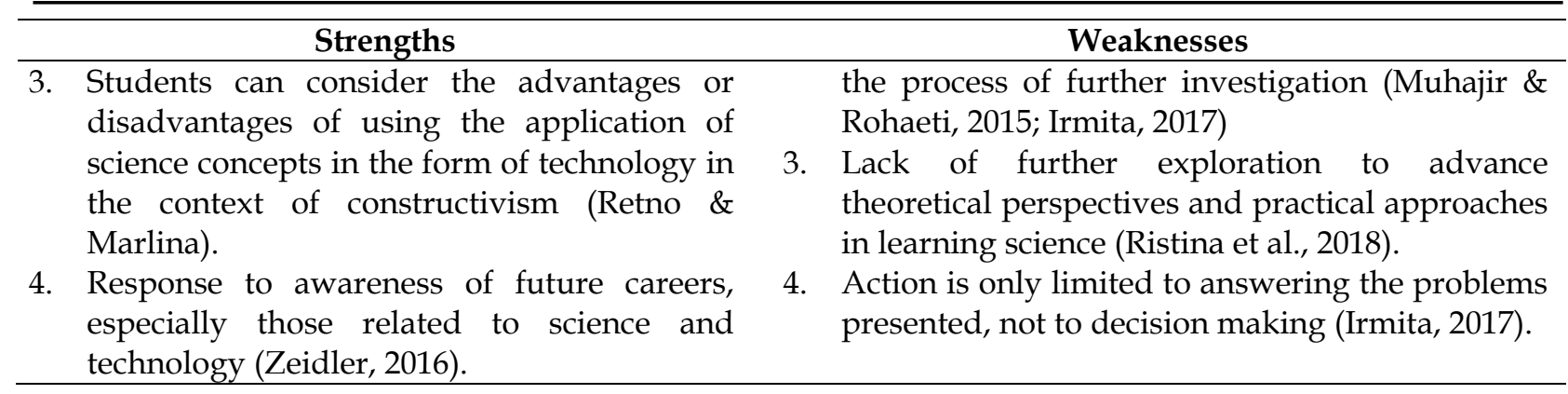

\section{DISCUSSION}

This hypothetical model is designed primarily to make students more active in seeking /digging information so that they can explain scientific phenomena, design and evaluate scientific inquiry, and interpret scientific data and evidence. The phases/syntax in this learning model is designed to be able to improve the ability of students' scientific literacy abilities that contribute positively to the indicators contained in scientific literacy. This hypothetical model was developed as an innovation of learning models that have been used to improve students' scientific literacy abilities, namely inquiry learning models and SETS (Science, Environment, Technology, society) learning model. From the strengths and weaknesses found in the application of the inquiry learning model and SETS that have been previously disclosed, information is obtained that not all stages of learning contained in both models contribute positively to the indicators contained in scientific literacy competencies. The differences in learning outcomes between Inquiry learning models and SETS, can be presented in the following Figure 2.

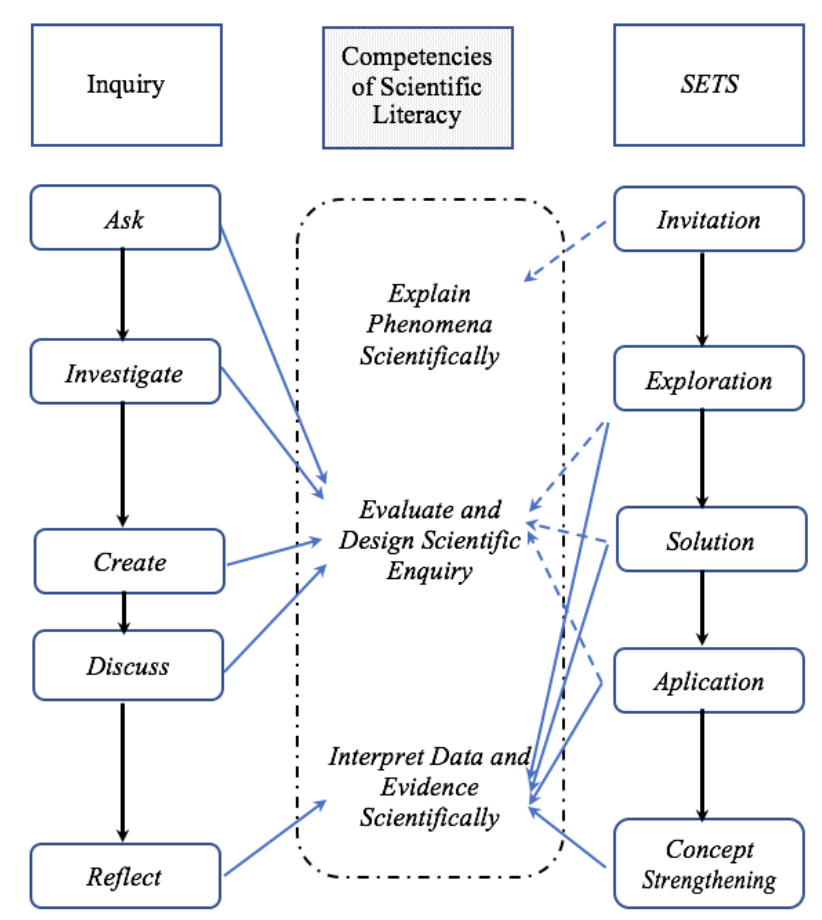

Figure 2. Differences in science literacy ability between models of Inquiry and SETS.

From Figure 2, it is designed the development of learning models that aim to improve the ability of scientific literacy by considering the strengths and weaknesses of the Inquiry model, and SETS so that the stages (syntax) of learning contained in the 
developed model contribute strongly to all indicators. indicators found in scientific literacy competencies. The model developed is to adapt and adopt ideas from the inquiry and SETS models and minimize the weaknesses caused by the two models.

Table 3. Synthesis of learning models developed.

\begin{tabular}{|c|c|c|c|}
\hline $\begin{array}{c}\text { Inkuiry } \\
\text { (Ong \& Borich, 2006) } \\
\end{array}$ & $\begin{array}{c}\text { SETS } \\
\text { (Poedjiadi, 2010) } \\
\end{array}$ & $\begin{array}{c}\text { Model } \\
\text { Developed }\end{array}$ & $\begin{array}{l}\text { Competencies of } \\
\text { Scientific Literacy }\end{array}$ \\
\hline & Invitation & $\begin{array}{l}\text { Brainstorming } \\
\text { Reading }\end{array}$ & $\begin{array}{l}\text { Explain Phenomena } \\
\text { Scientifically }\end{array}$ \\
\hline $\begin{array}{c}\text { Ask } \\
\text { (formulate questions or hypotheses) } \\
\text { Investigate } \\
\text { (planning an investigation) }\end{array}$ & Exploration & & \\
\hline $\begin{array}{c}\text { Create } \\
\text { (analyze data and interpret results) } \\
\text { Discuss } \\
\text { (discuss the findings of the } \\
\text { investigation and create } \\
\text { conclusions) }\end{array}$ & Application & Analyzing & $\begin{array}{l}\text { Evaluate and Design } \\
\text { Scientific Enquiry }\end{array}$ \\
\hline & & Decision Making & \\
\hline $\begin{array}{c}\text { Reflect } \\
\text { (reflect and create connections } \\
\text { between concepts) }\end{array}$ & $\begin{array}{c}\text { Concept } \\
\text { Strengthening }\end{array}$ & Reflection & $\begin{array}{c}\text { Interpret Data and } \\
\text { Evidence Scientifically }\end{array}$ \\
\hline
\end{tabular}

The learning model developed is named/labeled the BRADeR model. The naming of the model is based on an acronym of the five syntaxes/phase of the learning model, namely: brainstorming, reading, analyzing, decision making, and reflection. The rationality of developing models for each stage/syntax in the BRADeR learning model is as follows.

Phase 1st: Brainstorming. This phase is designed to prepare and communicate learning objectives to students so that they can generate initiative and maintain the student's willingness to learn, create curiosity and interest in what will be learned, focus attention and motivate students to play an active role in the problem-solving process. In this phase, the teacher concentrates on what problems are presented to students, how to present problems so students are interested, and think about what procedures are needed for students to achieve material goals and also other social goals such as cooperation in learning tasks. In this phase, the teacher also organizes learning needs. The teacher creates an atmosphere of learning-oriented to inquiry that is free, open, democratic, and positive so that students are free and free to develop ideas in their minds. Students are more active when the learning environment can stimulate and encourage independent thinking (Moreno, 2010).

This first phase is supported by several learning theories, including the ARCS theory (Attention, relevance, confidence, and satisfaction). This theory states that: students will be motivated if what is presented by the teacher can attract students' attention; Motivation can also be raised if what is taught is directly related to the needs of students (relevance); success in learning can increase self-confidence; and student satisfaction through learning initiatives that start from things that are simple, easy, interesting, and then will gradually present learning that is complex and more 
complicated (Arends, 2012). Next is the Advance Organizer theory which says that it is an initial statement about a material to be studied providing a structure for new information and linking that information with information obtained by students (Moreno, 2010); Meaningful learning states that mental processing of new information leads to knowledge that has been previously learned (Moreno, 2010); Constructivism Vygotsky states that if the teacher creates a brainstorming session for students to obtain a good memory strategy, then social construction will also be built (Santrock, 2014); Brainstorming can be done individually by writing down all solutions of ideas that flow to a phenomenon or solving problems (Jossey, 1998).

Phase 2nd: Reading. Reading in the learning activities intended in this phase is to understand, interpret, and articulate the discourse presented in the form of scientific problems. The main activity in this phase is students can select, understand, process, and remember information obtained through the text of the discourse presented. Furthermore, whether students have understood the problem in the discourse presented and see it as a puzzle, then whether they can ask questions to explain the problem, and can they present a summary of the problem when asked. In this phase, students are also expected to ask questions to gather information related to the problem. Students are expected to be able to ask questions based on facts (discourse text) and can provide responses when the teacher demonstrates how to ask questions.

This second phase is supported by several learning theories, including Accelerated Learning Theory, which states that learning not only uses the brain, but also involves the whole body/mind with all its emotions, senses, and nerves (Moreno, 2010); Scaffolding states that students should be given complex, difficult and realistic tasks and then be given sufficient assistance to solve the tasks given (Slavin, 2012; Nur, 2008); Reading comprehension is a process of reconstructing messages contained in reading text that is layered, interactive, and in it occurs the process of concept formation (Goodman, 1980); The teacher should provide support to students to explore and develop an understanding (Santrock, 2014).

Phase $3^{\text {th: }}$ Analyzing. This phase aims to investigate information gathering by conducting experiments through data collection and experimentation. Furthermore, an analysis of the problem-solving process of investigations in a collaborative form In this phase students are expected to develop process skills during an inquiry through the questions presented. Activities in this phase are students gathering information from various sources, students conducting investigations through experimental designs, students recording experimental data, matching data with investigated variables, processing data, representing the data through data analysis results.

This third phase is supported by several learning theories, including: Assisted Learing Theory, stating that the teacher guides teaching in such a way that students will complete mastery and flesh the skills that enable the functioning of higher cognitive knowledge (Moreno, 2010); Discovery Learning, states that students are encouraged to learn mostly through their active involvement individually or in groups with concepts and principles, and the teacher encourages students to have experience and conduct experiments that enable them to find principles for themselves (Nur, 2008; Moreno, 2010; Slavin, 2012); Information processing theory, states that students process information when they manipulate it, view information from various perspectives and analyze it (Slavin, 2012); Level of Processing Theory, states that people handle 
stimulation at different levels of mental processing and will only store information that has been handled through the most serious and deep processing (Nur, 2008; Slavin, 2012); Collaborative Learning, states that there are various ways to promote more active learning by presenting challenging material in their closest development zone (Moreno, 2010); Good pedagogy must involve students with the situations of students themselves who carry out experiments (Vygotsky in Nur, 2008); Learning discovery in accordance with the active search for knowledge by humans and by itself gives the best results (Dahar, 2011).

Phase $4^{\text {th: }}$ Decision Making. This phase aims to strengthen decision making from various alternative solutions obtained during the analysis activities. Learning activities carried out in this phase are to introduce problems that need to be taken decisions from the results of the investigation at the analysis stage, discuss and conclude the results of the investigation of problem-solving then plan a unit of questions to be asked. If students cannot take action spontaneously, the teacher will ask students to immediately start making several hypotheses of causation. The teacher comments on the ability of students to process and make these hypotheses. Next, organize some hypotheses and knowledge to make decisions. Students compare hypotheses as well as evaluating explanations about a phenomenon. When students can develop hypotheses, the teacher allows students to act by choosing one hypothesis that they believe to be true and then the students give a picture of the progress of all their thought processes.

This fourth phase is supported by several learning theories, including: Students must be encouraged not to rush into making decisions and consider all possibilities before trying to solve a problem (Nur, 2008; Moreno, 2010); Feedback Theory, which states that the most effective way to teach problem solving is to give students lots of practice, provides feedback not only on correct solutions but also on the process of how they can solve these problems (Nur, 2008; Moreno, 2010); Someone who has scientific literacy is someone who uses the concept of science, has the science process skills to assess and make daily decisions when dealing with other people, society and the environment (Holbrook \& Rannikmae, 2009); Science literacy refers to subjects who use the concept of science as an integrated skill by making decisions related to daily activities through technology, science, the environment, and society; decision making occurs in situations that require a person to make predictions ahead, choose one of two or more choices, make estimates for survival (Suharman, 2005).

Phase $5^{\text {th: }}$ Reflection. This phase aims to determine the level of success of students on the material that has been taught, to see whether students concentrate and provide correct responses to assignments, then to find out the wants and needs of students in detail, which can later be used as information in subsequent learning. In this phase, students are expected to be able to understand the learning objectives, be actively involved in the cognitive tasks that have been imposed on them. Learning activities carried out in this phase are: providing reinforcement and explanation related to the problem and concept being studied; provide input to conclusions obtained by students; and provides a summary of the material that has been studied and further work.

This fifth phase is supported by several learning theories, including: Theory of constructivism, states that students themselves must personally find and apply complex information, check new information compared to old rules and improve old rules if they are no longer appropriate (Nur, 2008; Moreno, 2010); Self-regulated learning occurs 
when there is a process of setting personal goals, combined with motivation, the process of thinking, strategy, and behavior leading to the achievement of goals (Eggen \& Kauchak, 2013); Learning through reflection when involved in the process of thinking about thinking and practice in a critical way, learning from the process, and determining what is learned to enhance future actions (Moreno, 2010); Reflect, states that to understand information is presented by: connecting information with things that are already known, linking subtopics in the text with the main concepts or principles, solving contradictions in the information presented, and using material it is to solve problems that are simulated and recommended from the subject matter (Nur, 2008; Slavin, 2012); Feedback is important for student motivation because it helps improve the quality of work perceptions of competence, self-determination, and intrinsic motivation (Eggen \& Kauchak, 2013).

Learning activities with the application of the BRADeR learning model expect active students. Student activeness greatly influences whether or not learning objectives are achieved. Besides the demand for student activity, the teacher also plays a role in learning activities to create a conducive and pleasant learning atmosphere. Deviant behaviors that occur during the learning process as soon as possible are handled by the teacher carefully and quickly. In the implementation of learning activities in class, pay attention to the activities of teachers and students that are designed on the BRADeR learning model. Teacher activities and student activities for each learning phase/syntax in the BRADeR learning model, are presented in the following Table 4.

Table 4. Teacher and student activities in each phase/syntax of learning in the BRADeR Learning Model.

\begin{tabular}{ll}
\hline \multicolumn{1}{c}{ Teacher Activities } & \multicolumn{1}{c}{ Student Activities } \\
\hline $\begin{array}{ll}\text { Phase 1: Brainstorming } & \\
\begin{array}{ll}\text { 1. Give initial questions before substance } \\
\text { questions }\end{array} & \begin{array}{l}\text { 1. Listen to the teacher's explanation. } \\
\text { 2. Observing and giving questions about the phenomenon } \\
\text { of the problem given. }\end{array} \\
\begin{array}{ll}\text { 2. Motivate students by giving simple problem } \\
\text { phenomena. }\end{array} & \begin{array}{l}\text { 3. Express ideas that are built through observation of the } \\
\text { phenomenon of the problem given. }\end{array} \\
\begin{array}{ll}\text { 3. Establish communication with students } \\
\text { through appeals to students to convey ideas. }\end{array} & \text { 4. Building communication between fellow teachers. } \\
\text { 4. Deliver learning objectives. } & \end{array}$
\end{tabular}

\section{Phase 2: Reading}

1. Presenting discourse (text) and asking students to read and understand scientific phenomena through discourse (text).

2. Ask students to summarize the main ideas contained in the discourse (text) associated with science

3. Encourage students to come up with ideas or opinions

4. Allow students to ask for information that is not yet understood.

5. Encourage students to identify and decide on the problem to be investigated.

Phase 3: Analyzing

1. Directing students to submit experiments that 1. Propose ideas in inquiry. will be tested.

2. Guiding students to plan an experiment to answer the problem of laboratory activities.
1. Read and understand discourse (text).

2. Summarize the main ideas contained in the discourse (text) associated with science.

3. Convey ideas or opinions.

4. Decide on the problem to be resolved.

5. Purpose a problem statement 


\section{Teacher Activities}

Student Activities

3. Guiding students in carrying out experiments concerning laboratory activities to obtain data.

4. Encourage students to dare to convey ideas and opinions.

5. Observe the course of investigation activities and remind students to be honest and thorough in taking data and interpreting data.

Phase 4: Decision Making

1. Guide students to express ideas.

2. Guide students to make decisions through analysis of available questions by considering the steps of decision making, in order: Create questions, Summing up information, Create choices, Create a list of pros and cons, Create decisions.

3. Guide students to conclude and discuss the results of the experiment.

Phase 5: Reflection

1. Provide reinforcement and explanation related to the problem and concept being studied.

2. Provide input for conclusions obtained by students.

3. Provide a summary of the material being studied and further assignments.

\section{Analyze data.}

1. Express ideas

2. Decide the analysis of the available guided questions

3. Present conclusions and discussion of the results of the experiment

1. Receive input into investigations.

2. Decide conclusions based on data and input from other students and teachers.

3. Receive and understand summaries of the material being studied.

4. Receive the next assignment.

\section{CONCLUSION}

Researchers have designed learning models based on theoretical and empirical studies; where it forms the syntax of the learning model as follows: 1) brainstorming; 2) reading; 3) analyzing; 4) decision making; and 5) reflection, so the learning model developed is called the BRADeR learning model. The BRADeR model was designed with the ultimate goal of improving the scientific literacy skills of junior high school students. Each phase of this learning model is expected to contribute positively to the indicators of scientific literacy which include: explaining scientific phenomena; design and evaluate scientific inquiry; and interpret data and evidence scientifically. The limitations of this study are still in the stage of developing the hypothetical BRADeR model. Further research is needed to prove that the BARDeR learning model is feasible by fulfilling aspects of validity, practicality, and effectiveness to improve the scientific literacy skills of junior high school students.

\section{ACKNOWLEDGEMENT}

Thank you to the Department of Technology Research and Higher Education for the scholarships given through BPPDN in 2017.

\section{REFERENCES}

Anam, K. (2015). Pembelajaran berbasis inkuiri: metode dan aplikasi. Yogyakarta. Pustaka Belajar.

Angraini, G. (2014). Analisis kemampuan literasi sains siswa SMA kelas X di kota solok. Prosiding mathematics and Science Forum 2014 Jurusan Biologi FPMIPA: Universitas Pendidikan Indonesia, 161-170. 
Arends, R. I. (2012). Learning to teach. New York: McGraw-Hill Companies.

Asyhari, A., \& Clara, G.P. (2017). Pengaruh pembelajaran level of inquiry terhadap kemampuan literasi sains siswa. Scientiae Educatia: Jurnal Pendidikan Sains, 6(2), 87-101. https://doi:/10.24235/sc.educatia.v6i2.2000

Basam, F., Rusilowati, A., \& Ridlo, S. (2018). Profil kompetensi sains siswa dalam pembelajaran literasi sains berpendekatan inkuiri saintifik. Pancasakti Science Educational Journal, 3(1), 1-8. https:// doi.org/10.24905/psej.v3i1.800

Brown, J.C. (2017). A meta-synthesis of the complementarity of culturally responsive and inquiry-based science education in k-12 settings: implications for advancing equiTable science teaching and learning. Journal of Research In Science Teaching, 54(9), 1143-117. https://doi.org/10.1002/tea.21401

Dahar, R.W. (2011). Teori-teori belajar dan pembelajaran. Jakarta: Erlangga.

DeBoer, G.E. (2000). Scientific literacy: Another look at its historical and contemporary meanings and its relationship to science education reform. Journal of Research in Science Teaching, 36(6), 582-601.

https://doi.org/10.1002/1098-2736(200008)37:6<582::AID-TEA5>3.0.CO;2-L

Eggen, Paul \& Kauchak, D. (2013). Strategi dan model pembelajaran. mengajarkan konten dan keterampilan berpikir. Jakarta: PT. Indeks.

Goodman. (1980). Reading strategies focus on Comprehension. Singapore: B\&J Enterprises PTE. Ltd.

Hasanah, I., Saptasari, M., \& Wulandari, N. (2017). Pengembangan instrumen penilaian kemampuan literasi sains siswa kelas xi materi sistem ekskresi dan koordinasi di SMAN 9 malang. Jurnal Pendidikan Biologi, 8(2), 52-56.

Holbrook, J., \& Rannikmae, M. (2009). The meaning of scientific literacy. International Journal of Environmental \& Science Education, 4(3), 275-288.

Huann, S.L., Zuway, R.H., \& Tai, C.H. (2012). The role of emotional factors in building public scientific literacy and engagement with science. International Journal of Science Education, 34(1), 25-42.

Irmita, L.U. (2017). Pengembangan perangkat pembelajaran menggunakan model pembelajaran sets untuk meningkatkan literasi sains. Jurnal Pendidikan Kimia, 2(1), 32-39.

Jossey, B. (1998). Brainstorming. The Pfeiffer Library, 26, 1-5.

Lederman, N. G., Lederman, J. S., \& Antink, A. (2013). Nature of science and scientific inquiry as contexts for the learning of science and achievement of scientific literacy. International Journal of Education in Mathematics, Science and Tecnology, 3(1), 138-147. https://ijemst.net/index.php/ijemst/article/view/19

McConney, A. (2014). Inquiry, engagement, and literacy in science: a retrospective, cross-national analysis using PISA 2006. Science Education Journal, 98(6), 963 980. https:/ / doi.org/10.1002/sce.21135

Moreno, R. (2010). Educational psychology. New York: John Wiley \& Sons, Inc.

Muhajir, S. \& Rohaeti, E. (2015). Perbedaan penerapan model pembelajaran sets dan ctl terhadap literasi sains dan prestasi belajar IPA. Jurnal Pendidikan Matematika Dan Sains, 3(2), 143-155.

Nur, M. (2008). Modul keterampilan-keterampilan proses sains. Surabaya: Unesa Press.

Odegaard, M., Haug, B., Mork, S., \& Sorvik, G.O. (2015). Building science and literacy. a classroom video study of the challenges and support in an integrated inquiry 
and literacy teaching model. Procedia-Social and Behavioral Science, 167, 274-278. doi:10.1016/j.sbspro.2014.12.674

OECD. (2013). PISA 2012. Assessment and analytical framework: mathematics, reading, science, problem solving and financial literacy. OECD Publishing. http:/ / dx.doi.org/10.1787/9789264190511-en.

OECD. (2016). PISA 2015 Results: What students know and can do - student performance in reading, mathematics and science (Volume $I$ ), $\mathrm{dx}$.doi.org.

OECD. (2017). PISA For development assessment and analitical framework: Reading, mathematics and science. www.oecd.org/about/publishing/corrigenda.htm.

Ong, A.C., \& Borich, G.D. (2006). Teaching strategies that promote thinking: models and curriculum approaches. Singapore: McGraw-Hill.

Poedjiadi, A. (2010). Sains teknologi masyarakat (Model pembelajaran kontekstual bermuatan nilai). Bandung. PT. Remaja Rosdakarya.

Putra, M.I.S., Widodo, W., \& Jatmiko, B. (2016). The development of guided inquiry science learning materials to improve science literacy skill of prospective mi teachers. Jurnal Pendidikan IPA Indonesia, 5(1), 83-93.

https://journal.unnes.ac.id/nju/index.php/jpii/article/view/5794

Rahayu, S. (2014). Menuju masyarakat berliterasi sains: Harapan dan Tantangan Kurikulum 2013. Prosiding Semiar Nasional Kimia dan Pembelajarannya (SNKP) 2014, 27-39.

Rakhmawan, A., Setiabudi, A., \& Mudzakir, A. (2015). Perancangan pembelajaran literasi sains berbasis inkuiri pada kegiatan laboratorium. Jurnal Penelitian dan Pembelajaran IPA, 1(1), 142-152. https:/ / core.ac.uk/reader/289792028

Retno, S. R., \& Marlina, D. (2018). Implementasi sets (science, environtment, tecnology, social) terhadap literasi sains siswa sd mojorejo madiun. Jurnal Ilmiah Kependidikan, 9(1), 33-39. https:/ / doi.org/10.24176/ re.v9i1.2806

Ristina, H., Linuwih, S., \& Nuswowati, M. (2018). Sets learning efficacy to improve students science literacy skills. Journal of Innovative Science Education, 7(2), 427433. DOI:10.15294/JISE.V0I0.27905

Rusilowati, A., Nugroho, S.E., Susilowati, S.M.E. (2016). Development of science textbook based on scientific literacy for secondary school. Jurnal Pendidikan Fisika Indonesia, 12(2), 98-105. https:/ / doi.org/10.15294/jpfi.v12i2.4252

Sani, A.R. (2014). Pembelajaran saintifik untuk implementasi Kurikulum 2013. Jakarta; P.T. Bumi Aksara.

Santrock, J.W. (2014). Educational psychology. New York: McGraw-Hill Company.

Situmorang, R.P. (2016). Integrasi literasi sains peserta didik dalam pembelajaran sains. Satya Widya, 32(1), 49-56.

Slavin, R.E. (2012). Educational psychology: Theory and practice. Massachusetts: Allyn and Bacon Publishers.

Suharnan. (2005). Psikologi kognitif. Surabaya: Srikandi.

Turiman, P., Omar, J., Daud, A.M., \& Osman, K. (2012). Fostering the 21st century skills through scientific literacy and science process skills. Procedia-Social and Behavior Sciences, 59(1), 110-116. https:// doi.org/10.1016/j.sbspro.2012.09.253

Wang, J., \& Zhao, Y. (2012). Comparative research on the understandings of nature of science and scientific inquiry between science teachers from Shanghai and Chicago. Journal of Baltic Science Education, 15(1), 97-108. 
http://www.scientiasocialis.lt/jbse/files/pdf/vol15/97108.Wang_JBSE_Vol.15 No.1.pdf

WEFUSA. (2015). World economic forum, new vision for education unlocking the potential of technology.

http:// www3.weforum.org/docs/WEFUSA_New-VisionforEducation_Report 2015.pdf.

Wenning, C.J. (2010). Using inquiry spectrum learning to teach science. Journal of Physics Teacher Education, 5(3), 11-17.

Yager, R.E. (1996). Science/Technology/Society as Perform in Science Education. Albany. State University of New York Press.

Zeidler, D.L. (2016). Stem education: a deficit framework for the twenty-first century? a sociocultural socioscientific response. Cultural Studies of Science Education, 1(1), 11-26. https://link.springer.com/article/10.1007/s11422-014-9578-z

\section{* Aprido B. Simamora (Corresponding Author)}

Postgraduate Doctoral Program of Science Education, Universitas Negeri Surabaya, Indonesia

Departement of Physics Education Faculty of Teacher Training and Education

HKBP Nommensen University Medan,

Jl. Sutomo No. 4A, Medan, North Sumatera, 20212, Indonesia

Email: prido_uhn@yahoo.co.id

\section{Dr. Wahono Widodo}

Department of Science Education Faculty of Mathematics Sciences,

Universitas Negeri Surabaya,

Jl. Ketintang-Gayungan, Surabaya, East Java, 60231, Indonesia

Email: wahonowidodo@unesa.ac.id

\section{Dr. I Gusti Made Sanjaya}

Department of Chemistry Faculty of Mathematics Sciences, Universitas Negeri Surabaya, Jl. Ketintang-Gayungan, Surabaya, East Java, 60231, Indonesia

Email: igmasanjaya@unesa.ac.id 